\title{
Effect of Dung Cake Biochar and NP Fertilizers on Growth and Yield of Carrot (Daucus carota L.) and Selected Soil Physico-Chemical Properties
}

\author{
Kenzemed Kassie ${ }^{1, a, *}$, Kibebew Kibret ${ }^{2, b}$, Tadele Amare ${ }^{3, c}$ \\ ${ }^{1}$ Debre Birhan Agricultural Research Center, P. O. Box 112, Debre Birhan, Ethiopia \\ ${ }^{2}$ Haramaya University $(\mathrm{Hu})$, Ethiopia \\ ${ }^{3}$ Adet Agricultural Research Center (ARC), Ethiopia \\ *Corresponding author
}

A R T I C LE IN F O A B S T R A C T

\section{Research Article}

Received : 31/12/2019

Accepted : 31/03/2020

\section{Keywords:}

Soil Amendment

Nitrogen

Phosphors

Dung Cake

Biochar

\begin{abstract}
Biochar as agricultural soil amendment to improve soil physico-chemical properties, crop productivity and sustainable soil fertility management is a well-known practice. A field experiment was conducted to evaluate the effect of biochar on growth and yield components of carrot and selected soil physic-chemical properties. The study was carried by employing a randomized complete block design with factorial arrangement of four level of biochar $(0,4,8$ and 12 tons ha-1) and four level of Nitrogen/Phosphorus (N/P) fertilizer rate (0/0,60/10, 90/15 and 120/20 $\left.\mathrm{kg} \mathrm{ha}^{-1}\right)$ with four replications. Biochar significantly influenced physico-chemical properties of soils, such as bulk density, total porosity, $\mathrm{pH}, \mathrm{EC}, \mathrm{SOC}, \mathrm{TN}, \mathrm{Av}$. $\mathrm{P}$ and $\mathrm{CEC}$ respectively, as compared to control. The results revealed substantial responses to biochar and N/P fertilization on growth and yield components of carrot with increasing level of biochar and N/P fertilizer rate. None of the others yield parameters were significantly affected by the interaction of two factors. From the present study, it can be concluded that dung cake biochar should be applied to enhance and improve soil physical and chemical properties for favourable plant growth.
\end{abstract}

\section{Introduction}

Biochar has been shown to improve soil fertility through various mechanisms and increase crop productivity (Glaser et al., 2002 and Lehmann et al., 2006). Given the rapid decomposition rates of crop residues and manures in tropical soils (Ayabana and Jenkinson, 1990) the much greater stability of charred biomass (Zimmerman, 2010) affords the possibility to improve soil organic matter levels and hence soil productivity (Lehmann, 2009).

Since $19^{\text {th }}$ century till now the energy sector has contributed to address improved stoves technology in Ethiopia (Melisew, 2002). However, such cook stoves still rely on woody feedstock. Currently new approach is developed to conventional cook stoves based on biomass burning is the pyrolysis of biomass; which affords the possibility to expand the feedstock options, and utilize nonwoody biomass to supplement woody biomass (Openshaw, 1998). In addition to cooking energy, pyro lytic cook stoves also generate a solid by-product, biochar, which can be used as a soil amendment (Lehman, 2007). Even though biochar had known its amendment effect on agricultural soils as optional source of integrated nutrient management in the world but the use of biochar is not clear.

Biochar can be produced from wide range of feedstocks such as animal manure, coffee husk, rice husk, and other crops residues. Biochars from plant materials are often low in nutrient content, particularly $\mathrm{N}$ (Chan et al., 2007)). Animal wastes are generally higher in nutrient content than plant wastes (Shinogi, 2004) as a result; biochar produced from animal origins may have more contribution to increase soil nutrient availability. On the other side small farmers the only faced problems to produce biochar is lack of very simple technique such as traditionally char making efforts to obtain a simple production method which yields a good quality biochar would be helpful (Utomo et al., 2011). 
There is little information on integrated application of biochar and inorganic fertilizer for agricultural use on crop production especially in relation to carrot production and its effect on soil physico-chemical properties. In view of the above background, this study was carried out with the objectives of evaluating the effect of cow dung cake biochar on selected soil physico-chemical properties and its effect on growth and yield of carrot.

\section{Materials and Methods}

\section{Description of the Study Area}

The study was conducted at Debre Birhan Agricultural Research Center (DBARC), Faji kebele of Debre Birhan Zuria District, which is located in North Shoa zone, Amhara Regional State, central Ethiopia (Figure 1). Debre Brihan is located at $130 \mathrm{~km}$ north of Addis Ababa. The geographical extent of Debre Birhan ranges from $09^{\circ} 35^{\prime}$ $45^{\prime \prime}$ to $09^{\circ} 36^{\prime} 45^{\prime \prime}$ north latitude and from $39^{\circ} 29^{\prime} 40^{\prime \prime}$ to $39^{\circ}$ 31' 30" east longitude with altitude of 2850 meters above sea level (Abayneh et al., 2006) (Figure 2).

According to the climatic records by Ethiopian National Meteorological Agency from 1985 to 2015, the mean annual rainfall at Debre Brihan is $934.17 \mathrm{~mm}$. It has unimodal rainfall pattern that has a maximum $293.07 \mathrm{~mm}$ and minimum $4.67 \mathrm{~mm}$ peaks in July and December, respectively. The mean annual maximum temperature is $19.82^{\circ} \mathrm{C}$ and monthly values range between $18.4^{\circ} \mathrm{C}$ in August and $21.8^{\circ} \mathrm{C}$ in June. The mean annual minimum temperature is $6.4^{\circ} \mathrm{C}$ and monthly values range between $2.8^{\circ} \mathrm{C}$ in November and $8.8^{\circ} \mathrm{C}$ in June. The coldest month occurs in November while the hottest months are May and June (Appendix Table 5-7 and Figure 2). Generally, the district, fall under tepid to cool sub moist mid highlands (SM2-8) agro-ecological zone. During growing season, the study area received a total of $144.7 \mathrm{~mm}$ of rainfall from February to June, 2015.

\section{Experimental Design, Treatments and Procedures}

The experimental design was factorial laid out in randomized complete block design with four replications. Combination of 4 levels of nitrogen/phosphorus (N/P) fertilizers $\left(0 / 0,60 / 10,90-15\right.$ and $120 / 20 \mathrm{~kg} \mathrm{ha}^{-1}$ of N/P) and dung cake biochar with four levels $\left(0,4,8\right.$, and $\left.12 \mathrm{t} \mathrm{ha}^{-1}\right)$ were used. Finally, the treatment combinations comprised of a total of 16 treatments including the control treatment (Table 1).

Seedbed preparation was done by hand digging with hoe at $25 \mathrm{~cm}$ depth in all beds using garden tools (forks and spade) according to the practices followed by the farmers in the study area for carrot production. The different rates of dung cake biochar were calculated on dry weight basis and the respective rates were added to each experimental plot two weeks before planting and incorporated in to the plough layer of the soil immediately after application.

The carrot seed of Nantes cultivar was drilled on rows at seed rate of $5 \mathrm{~kg} \mathrm{ha}^{-1}$ on $1.20 \mathrm{~m} \times 1 \mathrm{~m}$ plots (6 rows). Rows were spaced $20 \mathrm{~cm}$ from each other and at the time of first cultivation (three weeks after planting), thinning of carrot seedlings was done. The spacing between plants was $10 \mathrm{~cm}$. Each plot was watered equal amount for every treatment using watering cane as needed to keep the soil moist during the growing period and all agronomic management was kept uniform for all treatments. Nitrogen was applied as urea by splitting, 50\% at planting and the remaining amount was applied at full canopy cover of carrot. Moreover, phosphorus fertilizer was applied at planting of carrot in the form of Triple Supper Phosphate (TSP). In order to prevent effects in adjacent plots (border effects), $1 \mathrm{~m}$ border was made between plots and replications, respectively.

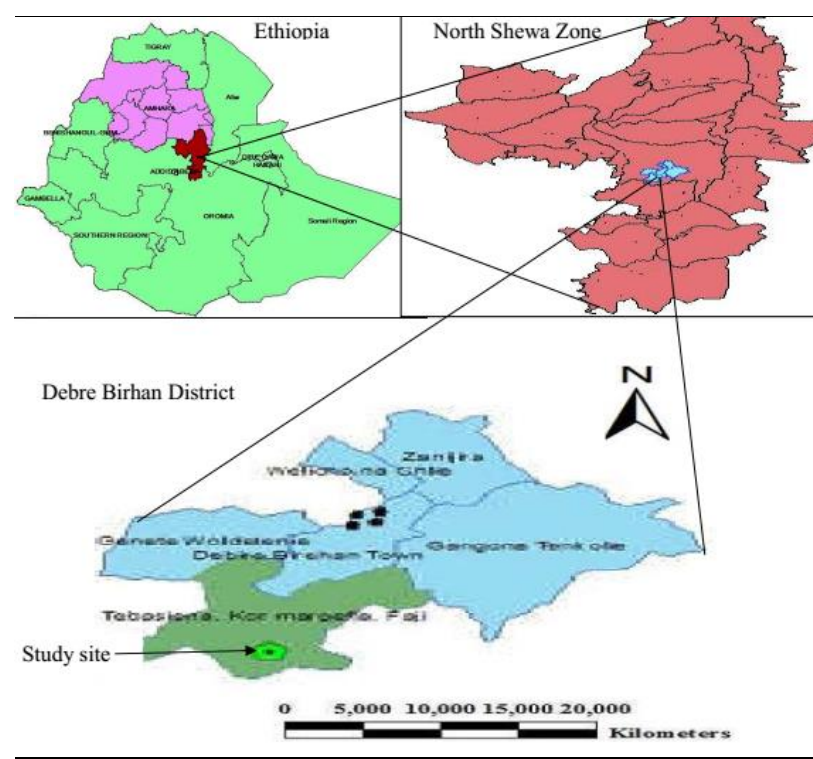

Figure 1. Map of the study area

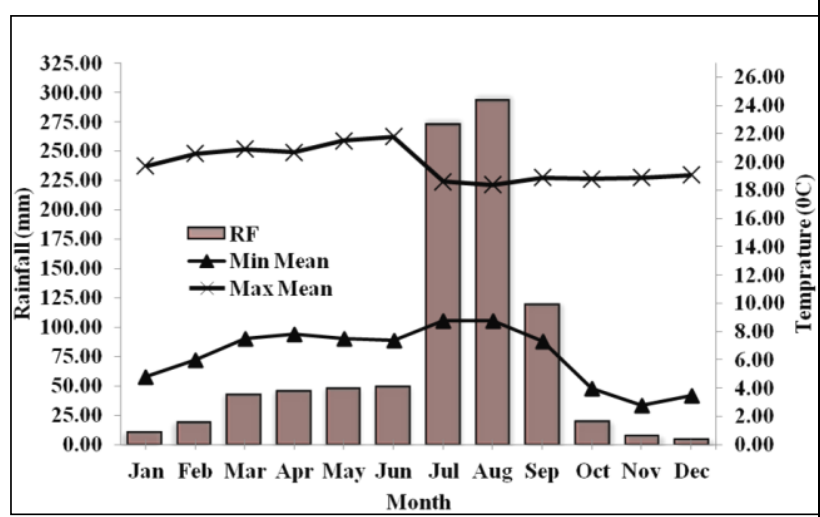

Figure 2. Monthly Rainfall and mean monthly minimum and maximum temperature the study area.

Table 1. Treatments details.

\begin{tabular}{l|cc}
\hline \multicolumn{1}{c|}{ Treatments } & $\mathrm{N} / \mathrm{P} \mathrm{kg} \mathrm{ha}^{-1}$ & Biochar t ha $^{-1}$ \\
\hline $\mathrm{T}_{1}=$ & $0 / 0$ & 0 \\
$\mathrm{~T}_{2}=$ & $60 / 10$ & 0 \\
$\mathrm{~T}_{3}=$ & $90 / 15$ & 0 \\
$\mathrm{~T}_{4}=$ & $120 / 20$ & 0 \\
$\mathrm{~T}_{5}=$ & $0 / 0$ & 4 \\
$\mathrm{~T}_{6}=$ & $60 / 10$ & 4 \\
$\mathrm{~T}_{7}=$ & $90 / 15$ & 4 \\
$\mathrm{~T} 8=$ & $120 / 20$ & 4 \\
$\mathrm{~T} 9=$ & $0 / 0$ & 8 \\
$\mathrm{~T} 10=$ & $60 / 10$ & 8 \\
$\mathrm{~T} 11=$ & $90 / 15$ & 8 \\
$\mathrm{~T} 12=$ & $120 / 20$ & 8 \\
$\mathrm{~T} 13=$ & $0 / 0$ & 12 \\
$\mathrm{~T} 14=$ & $60 / 10$ & 12 \\
$\mathrm{~T} 15=$ & $90 / 15$ & 12 \\
$\mathrm{~T} 16=$ & $120 / 20$ & 12 \\
\hline
\end{tabular}




\section{Sampling and Preparation of Dung cake Biochar}

Dung cake was collected from market in the study area where farmers use the dung for their own fuel source and market sale. The dung cakes were mixed and left to direct sunlight for ten days to attain uniform moisture content on air basis (Figure 3a). Randomly samples of dung cake were taken for nutrient analysis. Adapting the design of Venkatesh et al (2013) and Anderson (2009), oil drum was cut at the top of $15 \mathrm{~cm}$ for fitting to the remaining bottom part which served as outer chamber. From sheet of metal $33 \mathrm{~cm}$ diameter and $55 \mathrm{~cm}$ height chamber was prepared for gasifying of dung cake. During gasification, after flames stopped as soon as the burned chare was quenched with enough amount of water and dried on open air. Production temperature of biochar from dung cake was ranged from $450-550{ }^{\circ} \mathrm{C}$. All the required amount of dung cake that was turned into biochar was crushed with mortar and pestle and passed through $2 \mathrm{~mm}$ sieve size to avoid existence of different size particles while applying to the respective treatments (Figure 3b). After thoroughly mixing of the prepared biochar, composite sample was collected and dried in air and reserved for analysis of its chemical compositions, including the concentrations of Available Phosphorus (Av.P), total nitrogen (TN), organic carbon (OC), CEC, basic cations (Ca, $\mathrm{Mg}, \mathrm{K}$ and $\mathrm{Na}$ ), $\mathrm{pH}$ and $\mathrm{EC}$. Sub-samples was dried in oven dry at $105^{\circ} \mathrm{C}$ Finally, the moisture content calculated from fresh and air dry weights was used to determine the different rates of biochar which was applied for each treatment.

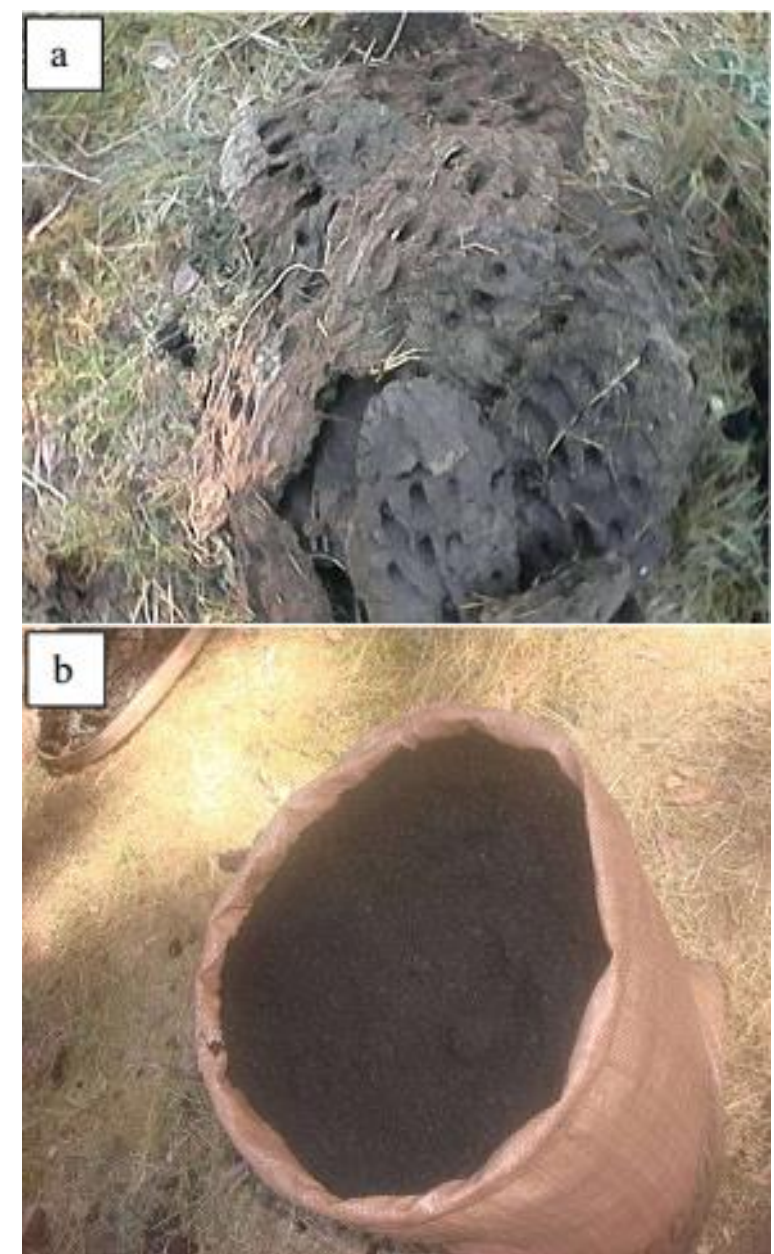

Figure 3. Dung cake not charred (a) and Dung cake charred (b)

\section{Soil Sampling and Preparation}

Prior to the field experimentation, two representative composite surface soil $(0-20 \mathrm{~cm}$ depth) samples were collected from the whole experimental field just before application of biochar and planting of carrot. Similarly, surface soil samples were collected from every replication of each plot of treatments, after harvesting. The collected soil samples both before planting and after harvest were dried in air and ground to pass through $2 \mathrm{~mm}$ sieve size for laboratory analysis of soil particle size distribution (texture), $\mathrm{pH}-\mathrm{H}_{2} \mathrm{O}, \mathrm{EC}, \mathrm{CEC}$, Av.P, exchangeable basic cations $(\mathrm{Ca}, \mathrm{Mg}, \mathrm{K}$, and $\mathrm{Na})$, and percent base saturation (PBS). The samples were crushed to pass through $0.5 \mathrm{~mm}$ to determine $\mathrm{OC}$ and $\mathrm{TN}$.

\section{Analysis of Soil and Biochar Samples}

Soil particle size distribution was analyzed using the Bouyoucos hydrometer method (Bouyoucos, 1962) after destroying organic matter $(\mathrm{OM})$ using hydrogen peroxide $\left(\mathrm{H}_{2} \mathrm{O}_{2}\right)$ and dispersed the soils with sodium hexameta phosphate $\left(\mathrm{NaPO}_{3}\right)$. Soil bulk density was measured by the core method (Black and Hartge, 1986). Undisturbed soil core samples were collected from the depths of $0-20 \mathrm{~cm}$ using a double cylinder core sampler. Each experimental plot was sampled from 3 random locations. The steel cores were caped from both sides, and transported to laboratory. The soil sample was weighed with analytical balance after 24 hours of oven drying at $105^{\circ} \mathrm{C}$ until constant weight is attained. Bulk density of soil was determined from the ratio of oven dry weight of soil to a known core sampler cylinder volume as:

$$
B D\left(\mathrm{gcm}^{-3}\right)=\frac{[(\operatorname{MDS}(\mathrm{g}))]}{\left[\left(\operatorname{VCS}\left(\mathrm{cm}^{3}\right)\right)\right]}
$$

Where, BD=Bulk density $\left(\mathrm{g} \mathrm{cm}^{-3}\right)$, MDS= Mass of oven dry soil and VCS=Volume of core sampler

Total porosity (TP) was calculated based on soil bulk density and average particle density of $2.65 \mathrm{~g} \mathrm{~cm}^{-3}$ for mineral soils using the following formula:

$$
T P(\%)=\left(1-\frac{B D}{\rho}\right) \times 100
$$

Where, $\mathrm{TP}=$ total porosity percentage, $\mathrm{BD}=$ bulk density and $\rho=$ particle density of mineral soils $\left(2.65 \mathrm{gcm}^{-3}\right)$

Soil $\mathrm{pH}$ was measured in $\mathrm{H}_{2} \mathrm{O}\left(\mathrm{pH}-\mathrm{H}_{2} \mathrm{O}\right)$ using 1:2.5 soil to solution ratio by $\mathrm{pH}$ meter as outlined by Van Reeuwijk (1992). Like soil samples, pH of biochar was measured potentiometrically using a $\mathrm{pH}$ meter.

Before charring of raw dung cake, OC, TN, and total phosphorus were determined following standard procedure of plant tissue analysis except OC content which was analyzed as described by Walkley and Black (1934). Similar method was used for determination soil OC following the wet oxidation method. The modified Kjeldahl procedure was followed for the determination of TN of soils and biochar as described by Jackson (1958). Available phosphorus in soil samples and $\mathrm{P}$ content in the biochar samples were extracted by Olsen extraction method (Olsen et al., 1954). The contents of P extractant were determined using spectrophotometer following the procedure described by (Murphy, 1968). 
CEC of the soil and biochar is determined by ammonium acetate method at $\mathrm{pH}$ 7. The concentration of liquid was determined by using Kjeldahl apparatus as ammonium after leaching of cations in the soils with $10 \% \mathrm{NaCl}$ solution. The concentrations of $\mathrm{Ca}$ and $\mathrm{Mg}$ in the extracts were measured using atomic absorption spectrophotometer while the content of $\mathrm{K}$ and $\mathrm{Na}$ in the same extract was determined using flame photometer. PBS of soil and biochar was also estimated from the sum of exchangeable bases as a percent of the CEC of the soil and biochar.

\section{Statistical Analysis}

The data collected from field experiment were subjected to analysis of variances (ANOVA) using general linear model procedure of the statistical analysis system (SAS Institute, 2002). Significant differences between treatment means were compared and separated using the least significant difference (LSD) at $\mathrm{P} \leq 0.05$. Similarly, simple correlation coefficients were carried out following standard statistical procedures.

\section{Results and Discussion}

\section{Soil Physicochemical Properties Before Planting}

The pre-experiment analysis of selected soil physical and chemical properties used in the study area presented in Table 2. The result of the textural analysis of the soil from the experiment site showed that the composition of clay, silt and sand percentage were $50.00,30.67$ and $19.33 \%$, respectively. Based on FAO (1990) soil textural classification, the soil is classified as clay soil. The soil had an average bulk density of $1.21 \mathrm{~g} \mathrm{~cm}^{-3}$. The $\mathrm{pH}$ of the soil is 6.12 which showed that the soil of the site was suitable for carrot production which is within a range of 6.0-7.5 (Getachew and Mohammed, 2013). According to Landon (1991), the soils were low in TN, moderate in Av.P, and low in OC and the $\mathrm{pH}$ was slightly acidic. Based on the rating of Landon (1991), the value of $\mathrm{CEC}$, exchangeable $\mathrm{Ca}$ and $\mathrm{Mg}$ of the soil were rated under high classes while exchangeable $\mathrm{K}$ and $\mathrm{Na}$ were also rated under very low and low respectively.

\section{Biochar Chemical Properties}

The laboratory results of chemical parameters for biochar and dung cake is indicated in Table 2 . The content of OC and TN in the raw dung cake is higher compared to the value obtained under charred dung cake. This might be due to loss of $\mathrm{C}$ and $\mathrm{N}$ in the gasifying processes. This is an agreement with many research results as reported on charring process significant proportions of biomass $\mathrm{N}$ are lost by volatilization (Chan and $\mathrm{Xu}, 2009$ ). However, the value of total $\mathrm{P}$ is much higher in the biochar compared to the original raw material. The variation was due to the release of $\mathrm{P}$ bounded in the organic form after charring of bulky raw dung cake.

\section{Soil Physicochemical Properties After Harvesting}

Soil bulk density and porosity were shown to be significantly $(\mathrm{P}<0.01)$ influenced by application of biochar. The lowest $\left(1.09 \mathrm{~g} \mathrm{~cm}^{-3}\right)$ and highest contents $\left(1.21 \mathrm{~g} \mathrm{~cm}^{-3}\right)$ of soil bulk density values were recorded plots that received biochar at of 12 and $0 \mathrm{t} \mathrm{ha}^{-1}$ respectively (Table 3). Application of biochar showed a decrease in soil bulk density by $11.01 \%$ at the rate of $12 \mathrm{t} \mathrm{ha}^{-1}$ compared to the control. The decrease in the bulk density of the soil may be attributed to the addition of biochar to the soils resulted in effects on the structure of the soil, which in turn, affects the total porosity. Organic matter also encourages aggregate formation and, thus, creates a more porous condition in the soil. Finally, the increased porosity reduced the bulk density. In addition to this, biochar also generally has lower density as compared to normal soil (Laird et al., 2010 and Jones et al., 2010). This finding is in line with several reports that found out the existence of significant differences in bulk density between soils with and without biochar (Laird et al., 2010; Pereira et al., 2012). Similarly, on weight basis of 5\% addition of biochar with soil, the bulk density was decreased by $31.48 \%$ after 105 days incubation and also the porosity improved by $21.95 \%$ as compared to soils without biochar (Jien and Wang, 2013).

Table 2. Physico-chemical characteristics of the experimental soil, biochar and dung cake

\begin{tabular}{l|cccc}
\hline \multicolumn{1}{c|}{ Parameter } & Unit & Soil & Biochar & Dung cake \\
\hline $\mathrm{pH} \mathrm{H} \mathrm{H}_{2} \mathrm{O}$ & - & 6.12 & 9.82 & - \\
$\mathrm{EC} * *$ & $\mathrm{dS} / \mathrm{m}$ & 0.053 & 1.04 & - \\
$\mathrm{OC}$ & $\%$ & 2.08 & 11.46 & 30.02 \\
$\mathrm{Total} \mathrm{N}$ & $\%$ & 0.20 & 0.79 & 1.39 \\
$\mathrm{C}: \mathrm{N}$ & - & 10.48 & 14.52 & 21.55 \\
$\mathrm{Av.P} / \mathrm{TP}^{\mathrm{b}}$ & $\mathrm{ppm}$ & 9.82 & 1313.40 & - \\
$\mathrm{CEC}$ & $\mathrm{cmol} / \mathrm{kg}^{-1}$ & 37.05 & 25.33 & - \\
Ex. Ca & $\mathrm{cmol} / \mathrm{kg}^{-1}$ & 17.99 & 69.12 & - \\
Ex. Mg & $\mathrm{cmol} / \mathrm{kg}^{-1}$ & 4.23 & 21.28 & - \\
Ex. K & $\mathrm{cmol} / \mathrm{kg}^{-1}$ & 0.13 & 0.79 & - \\
Ex. Na & $\mathrm{cmol} / \mathrm{kg}^{-1}$ & 0.23 & 0.35 & - \\
$\mathrm{PBS}$ & $\%$ & 61.19 & 362.06 & - \\
Sand & $\%$ & 19.33 & - & - \\
Silt & $\%$ & 30.67 & - & - \\
Clay & $\%$ & 50.00 & - & - \\
Textural Class & - & $\mathrm{Clay}$ & - \\
Bulk density & $\mathrm{g} \mathrm{cm}^{-3}$ & 1.21 & - & - \\
\hline
\end{tabular}

*Soil suspension 1:2.5, ** soil extract1:2.5 respectively; ${ }^{\mathrm{a}}$ available $\mathrm{P}$ for soil and biochar and ${ }^{\mathrm{b}}$ Total $\mathrm{P}$ for dung cake and - not determined. 
Total porosity of the studied soils ranged from 54.35 to $58.90 \%$ (Table 3). In general, change in porosity was brought by application of biochar at the rate of 4, 8 and 12 $\mathrm{kg} \mathrm{ha}^{-1}$ relative to the control. Application of 4 and $8 \mathrm{~kg} \mathrm{ha}^{-1}$ biochar did not show significant difference. The direct effects of biochar to high porosity and low bulk density could be the low density of biochar, which results increased soil porosity and weight dilution respectively (Sarah et al., 2014). Similarly, Zhang et al. (2012) revealed that addition of biochar with low bulk density and stable organic carbon reduces the penetration resistance and increase total soil porosity. This was also confirmed by a negative correlation between bulk density and soil organic carbon $(\mathrm{r}=-0.90)$ and application of BC ( $\mathrm{r}=-0.92)$ (Table 3).

There were significant differences $(\mathrm{P}<0.01)$ for $\mathrm{pH}$ $\left(\mathrm{H}_{2} \mathrm{O}\right)$ and electrical conductivity (EC) of soil with soil: water analysis of 1:2.5 after application of biochar. However, application of inorganic N/P fertilizer and the interaction effect of biochar and inorganic N/P on $\mathrm{pH}$ $\left(\mathrm{H}_{2} \mathrm{O}\right)$, and $\mathrm{EC}$ did not show significant effect.

The highest values of $\mathrm{pH}$ was recorded that plots received $12 \mathrm{t} \mathrm{ha}^{-1}$, while the lowest value also observed in the control after application of biochar (Table 4). The possible increment of $\mathrm{pH}\left(\mathrm{H}_{2} \mathrm{O}\right)$ value might be with increasing application rates of biochar, reflecting the fact that the liming potential increased with increasing application rates of biochar (Yuan and $\mathrm{Xu}$ 2011). In agreement with this result, Singh et al. (2010) reported that biochar had a positive ability to provide a liming effect which is depending on both the feedstock and processing temperature; increasing pyrolysis temperatures generally led to high $\mathrm{pH}\left(\mathrm{H}_{2} \mathrm{O}\right)$ values of biochars. The value of measured soil $\mathrm{pH}\left(\mathrm{H}_{2} \mathrm{O}\right)$ increment was positively correlated with application of biochar $\left(\mathrm{r}=0.89^{* * *}\right)$ and EC $\left(\mathrm{r}=0.87^{* *}\right)$. The increase in soil $\mathrm{pH}$ observed after the application of biochar might have been due to a release of cations from biochar, which had a positive response of $\mathrm{pH}$ $\left(\mathrm{H}_{2} \mathrm{O}\right)$ increase (Yuan and $\left.\mathrm{Xu}, 2011\right)$ (Table 4).

Application of biochar at rates of 4,8 , and $12 \mathrm{t} \mathrm{ha}^{-1}$ increased the EC by 56.7, 101.29 and $159.02 \%$, respectively, over the control. The results showed that EC increased with increasing biochar level (Table 3). This result is in agreement with the findings of Bayu et al. (2015), who reported that application of $15 \mathrm{t} \mathrm{ha}^{-1}$ coffee husk biochar increased soil EC from 0.02 to $0.09 \mathrm{mSm}^{-1}$ as compared to control. The observed increased in EC of the soil due to the application of biochar was generally attributed to an increase in ash content, dominated by carbonates of alkali and alkaline earth metals, phosphates and small amounts of organic and inorganic N (Arocena and Opio, 2003). Generally, the value of measured soil EC increment was positively correlated with application of biochar $\left(\mathrm{r}=0.98^{* *}\right), \mathrm{K}\left(\mathrm{r}=94^{* *}\right), \mathrm{Ca}\left(\mathrm{r}=75^{* *}\right)$ and $\mathrm{Mg}$ $\left(\mathrm{r}=0.84^{* *}\right)$ (Table 3$)$.

Table 3 shows that soil organic carbon (SOC), total nitrogen (TN), organic matter (OM) and $\mathrm{C}$ : $\mathrm{N}$ ratios of soils were significantly $(\mathrm{P}<0.01)$ affected by application of biochar. In the study, the amount of SOC content ranged from 2.58 to $2.96 \%$ for soils that received biochar at different rates (Table 3). As compared with the control, application of 12, 8 and $4 \mathrm{t} \mathrm{ha}^{-1}$ biochar increased soil organic carbon by $14.67,9.38$ and $5.75 \%$ respectively. The observed increase in SOM because of dung biochar application is in agreement with the reports of Marian et al. (2014) who found that cow dung biochar application at the rate of $40 \mathrm{t} \mathrm{ha}^{-1}$ increased soil organic carbon content by $49 \%$ and organic matter content by up to $94.4 \%$ over the control after two months of application. Abebe et al. (2015) also reported a $56.1 \%$ increase in soil organic matter with the application of maize stalk biochar at a rate of $20 \mathrm{t} \mathrm{ha}^{-1}$. However, as already mentioned above, application of biochar had shown statistically significant effect $(\mathrm{P}<0.01)$ as compared to non-treated soils, the status of SOC content of soils with and without biochar were rated as low according to tropical soil standard (Landon, 1991). SOC was also positively correlated with the increasing rates of biochar application $\left(\mathrm{r}=0.98^{* *},(\mathrm{P}<0.01)\right)$.

The amount of soil total nitrogen has showed similar pattern with SOC content. TN was significantly $(\mathrm{P}<0.01)$ increased as the rate of biochar rate was increased. Application of biochar increased TN\% from 0.21( $\left.0 \mathrm{t} \mathrm{ha}^{-1}\right)$ to $0.27 \%$ (12 $\mathrm{t} \mathrm{ha}^{-1}$ biochar). These result revealed that biochar had a great contribution to increase soil nitrogen content in post-harvest soils. Marian et al. (2014) reported that application of $40 \mathrm{t} \mathrm{ha}^{-1}$ of cow dung biochar increased soil TN by $31.25 \%$. Similarly, Abebe et al. (2012) reported that application of $20 \mathrm{t} \mathrm{ha}^{-1}$ of maize stalk biochar increased TN\% by $35 \%$ as compared to non-amended soil.

Soil available phosphorus was significantly $(\mathrm{P}<0.05)$ affected by application of biochar where the highest value (21.12) was obtained from the application of $12 \mathrm{t} \mathrm{ha}^{-1}$ biochar whereas the lowest value (10.93) was obtained from non-treated plot (Table 2). This could be due to the presence of high amount of available $\mathrm{P}$ in the biochar. A high $\mathrm{P}$ value at biochar treated soils has been reported by Lehmann (2007) and Abebe et al. (2012). Generally, there was a positive correlation between soil available $\mathrm{P}$ and application of biochar $\left(\mathrm{r}=0.63^{*}\right), \mathrm{pH}\left(\mathrm{H}_{2} \mathrm{O}\right)\left(\mathrm{r}=0.65^{*}\right)$ and OC $\left(r=0.62^{*}\right)$.

Table 3. Effects of dung cake biochar on soil physical and chemical properties

\begin{tabular}{l|ccccccccc}
\hline $\begin{array}{c}\mathrm{BC} \\
\left(\mathrm{t} \mathrm{ha}{ }^{-1}\right)\end{array}$ & $\begin{array}{c}\mathrm{BD} \\
\left(\mathrm{g} \mathrm{cm}^{-3}\right)\end{array}$ & $\begin{array}{c}\mathrm{TP} \\
(\%)\end{array}$ & $\begin{array}{c}\mathrm{pH} \\
\left(\mathrm{H}_{2} \mathrm{O}\right)\end{array}$ & $\begin{array}{c}\mathrm{EC} \\
(\mu \mathrm{s} / \mathrm{cm})\end{array}$ & $\begin{array}{c}\text { SOC } \\
(\%)\end{array}$ & $\begin{array}{c}\text { TN } \\
(\%)\end{array}$ & $\begin{array}{c}\text { OM } \\
(\%)\end{array}$ & $\begin{array}{c}\text { C:N } \\
(\mathrm{pvm})\end{array}$ \\
\hline 0 & $1.21^{\mathrm{a}}$ & $54.35^{\mathrm{c}}$ & $6.06^{\mathrm{c}}$ & $140.52^{\mathrm{d}}$ & $2.58^{\mathrm{c}}$ & $0.21^{\mathrm{c}}$ & $4.34^{\mathrm{c}}$ & $12.40^{\mathrm{a}}$ & $10.93^{\mathrm{c}}$ \\
4 & $1.15^{\mathrm{b}}$ & $55.34^{\mathrm{bc}}$ & $6.28^{\mathrm{b}}$ & $220.20^{\mathrm{c}}$ & $2.73^{\mathrm{b}}$ & $0.25^{\mathrm{b}}$ & $4.61^{\mathrm{b}}$ & $10.94^{\mathrm{b}}$ & $17.87^{\mathrm{b}}$ \\
8 & $1.14^{\mathrm{b}}$ & $56.96^{\mathrm{b}}$ & $6.43^{\mathrm{b}}$ & $282.85^{\mathrm{b}}$ & $2.82^{\mathrm{b}}$ & $0.26^{\mathrm{b}}$ & $4.84^{\mathrm{a}}$ & $11.02^{\mathrm{b}}$ & $18.14^{\mathrm{b}}$ \\
12 & $1.09^{\mathrm{c}}$ & $58.90^{\mathrm{a}}$ & $6.61^{\mathrm{a}}$ & $363.98^{\mathrm{a}}$ & $2.96^{\mathrm{a}}$ & $0.27^{\mathrm{a}}$ & $5.01^{\mathrm{a}}$ & $11.04^{\mathrm{b}}$ & $21.12^{\mathrm{a}}$ \\
LSD (0.05) & 0.02 & 1.69 & 0.17 & 22.04 & 0.12 & 0.011 & 0.23 & 0.75 & 2.87 \\
$\mathrm{CV}(\%)$ & 2.94 & 2.24 & 3.74 & 12.29 & 5.99 & 6.06 & 6.72 & 9.31 & 23.79 \\
\hline
\end{tabular}

Means within the same factor and column followed by the same letter are not significantly different at $\mathrm{P} \geq 0.05$ level of significance; $n s=$ Non significant; Biochar=BC Bulk Density=BD; Total porosity=TP SOC=soil organic carbon; TN=Total Nitrogen; OM=organic matter a; $\mathrm{C}: \mathrm{N}=$ carbon nitrogen ratio and Av.P=Available phosphorus 
Table 4. Simple correlation coefficients of biochar and selected soil physical and chemical parameters

\begin{tabular}{|c|c|c|c|c|c|c|c|c|c|c|c|c|c|}
\hline & $\mathrm{BC}$ & $\mathrm{pH}$ & $\mathrm{EC}$ & CEC & $\mathrm{Na}$ & $\mathrm{K}$ & $\mathrm{Ca}$ & $\mathrm{Mg}$ & $\mathrm{BS}$ & Av.P & $\mathrm{BD}$ & $\mathrm{TP}$ & $\mathrm{OC}$ \\
\hline$\overline{\mathrm{BC}}$ & 1.00 & & & & & & & & & & & & \\
\hline $\mathrm{pH}$ & $0.89^{* *}$ & 1.00 & & & & & & & & & & & \\
\hline $\mathrm{EC}$ & $0.98^{* *}$ & $0.87^{* *}$ & 1.00 & & & & & & & & & & \\
\hline CEC & $0.82^{* *}$ & $0.60^{*}$ & $0.80^{* *}$ & 1.00 & & & & & & & & & \\
\hline $\mathrm{Na}$ & $0.33^{\mathrm{ns}}$ & $0.17^{\mathrm{ns}}$ & $0.38^{\mathrm{ns}}$ & $0.25^{\mathrm{ns}}$ & 1.00 & & & & & & & & \\
\hline $\mathrm{K}$ & $0.96^{* *}$ & $0.77^{* * *}$ & $0.94^{* *}$ & $0.90^{* *}$ & $0.35^{\mathrm{ns}}$ & 1.00 & & & & & & & \\
\hline $\mathrm{Ca}$ & $0.76^{* *}$ & $0.80^{* *}$ & $0.75^{* *}$ & $0.48^{\text {ns }}$ & $0.14^{\mathrm{ns}}$ & $0.61^{*}$ & 1.00 & & & & & & \\
\hline $\mathrm{Mg}$ & $0.86^{* *}$ & $0.81^{* *}$ & $0.84^{* *}$ & $0.71^{* *}$ & $0.22^{\mathrm{ns}}$ & $0.86^{* *}$ & $0.66^{*}$ & 1.00 & & & & & \\
\hline $\mathrm{BS}$ & $0.54^{*}$ & $0.65^{*}$ & $0.54^{*}$ & $0.16^{\mathrm{ns}}$ & $0.05^{\mathrm{ns}}$ & $0.35^{\mathrm{ns}}$ & $0.94^{* *}$ & $0.45^{\mathrm{ns}}$ & 1.00 & & & & \\
\hline Av.P & $0.63^{*}$ & $0.65^{*}$ & $0.58^{*}$ & $0.48^{\mathrm{ns}}$ & $0.22^{\mathrm{ns}}$ & $0.58 *$ & $0.62^{*}$ & $0.41^{\mathrm{ns}}$ & $0.56^{*}$ & 1.00 & & & \\
\hline BD & $-0.92^{* *}$ & $-0.92^{* *}$ & $-0.90^{* *}$ & $-0.69^{* *}$ & $-0.21^{\mathrm{ns}}$ & $-0.84^{* *}$ & $-0.80^{* *}$ & $-0.79^{* *}$ & $-0.64^{*}$ & $-0.66^{*}$ & 1.00 & & \\
\hline $\mathrm{TP}$ & $0.80^{* * *}$ & $0.79^{* *}$ & $0.75^{* *}$ & $0.68^{* *}$ & $0.01^{\mathrm{ns}}$ & $0.78^{* * *}$ & $0.59 *$ & $0.65^{*}$ & $0.41^{\mathrm{ns}}$ & $0.58^{*}$ & $-0.85^{* *}$ & 1.00 & \\
\hline $\mathrm{OC}$ & $0.98^{* *}$ & $0.82^{* *}$ & $0.95^{* *}$ & $0.85^{* *}$ & $0.39^{\mathrm{ns}}$ & $0.96^{* *}$ & $0.71^{* *}$ & $0.84^{* *}$ & $0.48^{\mathrm{ns}}$ & $0.62^{*}$ & $-0.90^{* *}$ & $0.75^{* *}$ & 1.00 \\
\hline $\mathrm{TN}$ & $0.69^{* *}$ & $0.70^{* *}$ & $0.66^{*}$ & $0.50^{*}$ & $0.12^{\mathrm{ns}}$ & $0.63^{*}$ & $0.60^{*}$ & $0.43^{\mathrm{ns}}$ & $0.49^{\text {ns }}$ & $0.78^{* *}$ & $-0.69^{* *}$ & $0.51^{*}$ & $0.66^{*}$ \\
\hline
\end{tabular}

$\mathrm{NS},{ }^{*},{ }^{* *}=$ Non significant, Significant at $<0.05$, and $<0.01$ probability level; $\mathrm{BC}=$ biochar, $\mathrm{pH}=\mathrm{pH}$ of water, EC=electrical conductivity, CEC $=$ Cations exchange capacity, Av.P=available $\mathrm{P}, \mathrm{TP}=$ total porosity, $\mathrm{OC}=$ organic carbon, $\mathrm{TN}=$ total nitrogen

Table 5. Effects of dung cake biochar rates on soil CEC and exchangeable bases ( $\mathrm{Na}, \mathrm{K}, \mathrm{Ca}$ and $\mathrm{Mg}$ )

\begin{tabular}{|c|c|c|c|c|c|c|}
\hline \multirow{2}{*}{$\begin{array}{c}\text { Biochar } \\
\left(\mathrm{t} \mathrm{ha}^{-1}\right)\end{array}$} & CEC & $\mathrm{Na}$ & K & $\mathrm{Ca}$ & $\mathrm{Mg}$ & \multirow{2}{*}{$\begin{array}{l}\text { PBS } \\
(\%)\end{array}$} \\
\hline & \multicolumn{5}{|c|}{$(\mathrm{cmol} / \mathrm{kg})$} & \\
\hline 0 & $38.96^{\mathrm{c}}$ & 0.24 & $0.11^{\mathrm{d}}$ & $21.24^{\mathrm{c}}$ & $5.68^{c}$ & $63.74^{b}$ \\
\hline 4 & $40.18^{b c}$ & 0.24 & $0.13^{\mathrm{c}}$ & $24.50^{\mathrm{b}}$ & $5.70^{\mathrm{c}}$ & $70.51^{\mathrm{a}}$ \\
\hline 8 & $41.21^{\mathrm{ab}}$ & 0.24 & $0.17^{b}$ & $25.45^{\mathrm{b}}$ & $5.92^{\mathrm{b}}$ & $71.29^{\mathrm{a}}$ \\
\hline 12 & $42.43^{\mathrm{a}}$ & 0.24 & $0.22^{\mathrm{a}}$ & $27.54^{\mathrm{a}}$ & $6.37^{\mathrm{a}}$ & $74.49^{\mathrm{a}}$ \\
\hline $\operatorname{LSD}(0.05)$ & 1.82 & ns & 0.01 & 1.08 & 0.15 & 4.30 \\
\hline $\mathrm{CV}(\%)$ & 6.26 & 4.72 & 10.44 & 6.19 & 3.48 & 8.68 \\
\hline
\end{tabular}

As shown in Table 5, the lowest CEC and exchangeable bases $(\mathrm{Na}, \mathrm{K}, \mathrm{Ca}, \mathrm{Mg}$,) were observed from the control. Application of $12 \mathrm{t} \mathrm{ha}^{-1}$ produced the highest CEC, followed by soils treated with $8 \mathrm{tha}^{-1}$ of biochar. There was no significance different between CEC of the soils that received $4 \mathrm{tha}^{-1}$ and $8 \mathrm{tha}^{-1}$ biochar. Based on this finding, CEC did not increase in proportion to the application rates of biochar. However, application of 4,8 and $12 \mathrm{t} \mathrm{ha}^{-1}$ increased CEC by $3.13 \%, 5.78 \%$ and $8.91 \%$ as compared to the control. Most research report conform that biochar application increase soil CEC as the result of inherent characteristics of biochar, such as high surface area (Lehman et al., 2006; Glaser et al., 2002).

The application of biochar significantly affected $(\mathrm{P}<0.01)$ exchangeable $\mathrm{K}, \mathrm{Ca}$ and $\mathrm{Mg}$ of soil (Table 5). The exchangeable $\mathrm{K}, \mathrm{Ca}$, and $\mathrm{Mg}$ increased after amendment of the soil with dung cake biochar. Study result by Bayu et al. (2015) revealed that application of coffee husk biochar at the rate of $15 \mathrm{tha}^{-1}$ increased exchangeable $\mathrm{K}, \mathrm{Ca}$ and $\mathrm{Mg}$ by $52.52,48.61$ and $61.55 \%$ respectively. The observed exchangeable $\mathrm{K}, \mathrm{Ca}$ and $\mathrm{Mg}$ amount might be increased due to the immediate release of mineral cations to the soils (Niemeyer et al., 2005). The application of biochar also significantly affected $(\mathrm{P}<0.05) \mathrm{PBS}$ of soil (Table 5). The maximum PBS was found in soils amended with biochar at the rate of $12 \mathrm{t} \mathrm{ha}^{-1}$ which were statistically identical with treatment 4 and $8 \mathrm{tha}^{-1}$ biochar. These results revealed that biochar had a great contribution to increase PBS in postharvest soils. According to Jien et al. (2013), application of $5 \%$ biochar on weight basis increased PBS from 6.40 to 26.0\%. Similarly, Martinsen et al. (2014) reported that application of $6 \mathrm{tha}^{-1}$ of maize cobs biochar on three types of soils increased PBS as compared to non-amended soil.

\section{Growth and Yield Component Carrot}

There were significant differences $(\mathrm{P}<0.01)$ the main effects of biochar and NP fertilizer application for all means of growth and yield components of carrot. Plant height was increased significantly with increasing rate of biochar. The highest value of plant height (28.78) was recorded at the rate of $12 \mathrm{t} \mathrm{ha}^{-1}$ of biochar, while the lowest $(25.48 \mathrm{~cm})$ was obtained from control (Table 4). Vivek and Chakor (1992) found that plant height of sunflower increased by biochar application. As reported by Ellen et al. (2010) reported an average increase of $39 \%$ in potato plant height due to the use of biochar prepared from citrus wood in a traditional charcoal pit. Generally, the application rate of biochar was significantly and positively correlated with plant height $(\mathrm{r}=$ $0.83^{* *}$ ) as shown in Table 5 .

The increase in height due to increasing rate of inorganic $\mathrm{N} / \mathrm{P}$ fertilizers had brought the maximum plant height of carrot at $120 / 20 \mathrm{~kg} \mathrm{ha}^{-1}$ of N/P while the lowest was recorded from the control (Table 6). Application of 120/20 and 90/15 kg ha${ }^{1} \mathrm{~N} / \mathrm{P}$ increased plant height by 20.9 and $13.02 \%$ over the control, respectively. Sisay et al. (2008) found that higher levels of $\mathrm{N}$-fertilizer application (342.5 and $411 \mathrm{~kg} \mathrm{ha}^{-1}$ Urea) promoted the plant height significantly.

Similar to plant height, the root length of carrot was significantly $(\mathrm{P}<0.01)$ influenced by application of biochar. The longest root $(15.96 \mathrm{~cm})$ was obtained by application of biochar at $12 \mathrm{t} \mathrm{ha}^{-1}$ whereas the lowest root length of carrot (13.89) was recorded from control treatment (Table 6). This result showed that the root length progressively increased with increased rate of biochar from 0 to $4 \mathrm{t} \mathrm{ha}^{-1}$. But there was no statistically significant difference among the application of 4,8 and $12 \mathrm{t} \mathrm{ha}^{-1}$ biochar. The findings of this research result agreed with 
many research reports that biochar applications to soils increased plant growth, and crop yields (Lehmann et al., 2003; Rondon et al., 2007; Graber et al., 2010).

Root diameter exhibited significant variation among application of different rates of biochar (Table 6). The root diameter was increased with increased rate of biochar up to $8 \mathrm{t} \mathrm{ha}^{-1}$. The highest root diameter $(31.38 \mathrm{~mm})$ was obtained from a treatment with biochar applied at the rate of $12 \mathrm{tha}^{-1}$ which was similar to that of $8 \mathrm{t} \mathrm{ha}^{-1}(31.45 \mathrm{~mm})$ of biochar. On the other hand, the lowest root diameter $(27.05 \mathrm{~mm})$ was obtained from the control.

In the same way, the maximum root diameter $(30.85$ $\mathrm{mm}$ ) was found from the application of $120 / 20 \mathrm{~kg} \mathrm{ha}^{-1}$ of N/P fertilizer which was similar to that of $90 / 15 \mathrm{~kg} \mathrm{ha}^{-1} \mathrm{~N} / \mathrm{P}$ application while the minimum $(28.58 \mathrm{~mm})$ root diameter was obtained from the control. Root diameter increased by $1.32,1.99$ and $2.27 \mathrm{~mm}$, with increased application of N/P fertilizer from 0/0 N/P kg ha-1 to 60/10 N/P kg ha-1 90/15 N/P kg ha ${ }^{-1}$ and 120/20 N/P kg ha ${ }^{-1}$, respectively. Similar result was reported by Zakir et al. (2012) that application of $90-30 \mathrm{~kg} \mathrm{ha}^{-1} \mathrm{~N} / \mathrm{P}$ fertilizer increased root diameter of carrot from $7.04 \mathrm{~mm}$ to $10.91 \mathrm{~mm}$.

With regard to root core diameter, the highest value was observed with the application of biochar at the rate of $12 \mathrm{t}$ $\mathrm{ha}^{-1}$ that is greater than control by $13.80 \%$. It is found that the root core diameter is significantly greater $(7.23$ and $9.20 \%$ ) by the addition of 4 and $8 \mathrm{t} \mathrm{ha}^{-1}$ of biochar over the control one, respectively.

The mean value clearly showed that root core diameter of carrot increased with an increase in level of N/P fertilizer
(Table 4). The maximum root core diameter (12.02 $\mathrm{mm}$ ) was recorded in $120 / 20 \mathrm{~kg} \mathrm{ha}^{-1} \mathrm{~N} / \mathrm{P}$ fertilizer, similarly followed by $90 / 15 \mathrm{~kg} \mathrm{ha}^{-1} \mathrm{~N} / \mathrm{P}$ fertilizer application rate $(11.93 \mathrm{~mm})$. Both of these treatments behaved nonsignificantly with each other. Minimum root core diameter $(10.78 \mathrm{~mm})$ was recorded in control. Further applications of N/P fertilizer above 90/15 kg ha-1 did not bring significant effect and suggesting $90 / 15 \mathrm{~kg} \mathrm{ha}^{-1}$ is the maximum rate to obtain highest root core diameter of carrot. Shafique (2016) and Sisay (2008) also reported that root core diameter of carrot markedly increased with nitrogen and phosphorus fertilizer application.

Application of 4, 8 and $12 \mathrm{t} \mathrm{ha}^{-1}$ biochar increased root volume by about $41.26,31.88$ and $12.03 \%$, respectively compared to the control (Table 7). The positive response of root volume of carrot could be the presence of favorable physical soil properties as well as the nutrient supplying capacity of biochar. Similarly, application of biochar for commercial grower of cucumber at the rate of $4 \mathrm{~g} \mathrm{l}^{-1}$ as growing media, root volume of these plants was $34 \%$ higher than in the control (Muter et.al, 2014).

The data revealed highly significant $(\mathrm{P}<0.01)$ effect of $\mathrm{N} / \mathrm{P}$ fertilizer rate on root volume. The rate increased significantly the root volume (Table 7). Maximum root volume $\left(68.28 \mathrm{~cm}^{3}\right)$ was observed in $120 / 20 \mathrm{~kg} \mathrm{NP}$ fertilizer followed by $90 / 15,60 / 10$ and $0 / 0 \mathrm{~kg} \mathrm{ha}^{-1} \mathrm{~N} / \mathrm{P}$ fertilizer with an average root volume of $62.49,56.57$, and $52.25 \mathrm{~cm}^{3}$ respectively. All these treatments were differed significantly. Minimum root volume $\left(52.25 \mathrm{~cm}^{3}\right)$ was recorded in the control.

Table 6. Simple correlation coefficients (r) values between growth parameters, total root yield and yield components of carrot

\begin{tabular}{|c|c|c|c|c|c|c|c|c|c|c|}
\hline & $\mathrm{BC}$ & $\mathrm{PH}$ & RL & RD & RV & TRY & MY & UMY & FRY & CRY \\
\hline $\mathrm{BC}$ & 1.00 & $0.83^{* *}$ & $0.58^{*}$ & $0.44^{\mathrm{ns}}$ & $0.59^{*}$ & $0.51^{*}$ & $0.53^{*}$ & $0.52^{*}$ & $0.43^{\text {ns }}$ & $0.48^{\mathrm{ns}}$ \\
\hline PH & & 1.00 & $0.82^{* *}$ & $0.79^{* *}$ & $0.89^{* *}$ & $0.79^{* *}$ & $0.78^{* *}$ & $0.68^{*}$ & $0.62^{*}$ & $0.63^{*}$ \\
\hline RL & & & 1.00 & $0.76^{* *}$ & $0.89^{* *}$ & $0.78^{* *}$ & $0.73^{* *}$ & $0.76^{* *}$ & $0.72^{* *}$ & $0.53^{*}$ \\
\hline RD & & & & 1.00 & $0.94^{* *}$ & $0.85^{* *}$ & $0.89^{* *}$ & $0.65^{*}$ & $0.62^{*}$ & $0.64^{*}$ \\
\hline RV & & & & & 1.00 & $0.87^{* *}$ & $0.88^{* *}$ & $0.78^{* *}$ & $0.76^{\text {** }}$ & $0.68^{* *}$ \\
\hline TRY & & & & & & 1.00 & $0.97^{* *}$ & $0.89^{* *}$ & $0.86^{* * *}$ & $0.67^{* *}$ \\
\hline MY & & & & & & & 1.00 & $0.72^{* *}$ & $0.69^{* *}$ & $0.56^{*}$ \\
\hline UMY & & & & & & & & 1.00 & $0.96^{* * *}$ & $0.67^{* *}$ \\
\hline FRY & & & & & & & & & 1.00 & $0.49^{\text {ns }}$ \\
\hline
\end{tabular}

NS, ${ }^{*}, * *=$ Non-significant, Significant at 0.05 and 0.01 Probability Level; BC=biochar, PH=Plant Height; RL= Root Length, RD= Root Diameter, $\mathrm{RV}=$ Root Volume, TRY=Total Root Yield, MY=Marketable Yield, UMY= Unmarketable Yield, FRY=Forked Root Yield, CRY=Cracked Root Yield.

Table 7. Effects of dung cake biochar and inorganic NP fertilizer rates on carrot growth parameters

\begin{tabular}{|c|c|c|c|c|c|c|}
\hline & $\begin{array}{c}\mathrm{PH} \\
(\mathrm{cm})\end{array}$ & $\begin{array}{c}\mathrm{RL} \\
(\mathrm{cm})\end{array}$ & $\begin{array}{c}\mathrm{NL} \\
\left(\mathrm{P}^{-1}\right)\end{array}$ & $\begin{array}{c}\mathrm{RD} \\
(\mathrm{mm})\end{array}$ & $\mathrm{RCD}(\mathrm{mm})$ & $\begin{array}{c}\mathrm{RV} \\
\left(\mathrm{cm}^{3}\right)\end{array}$ \\
\hline \multicolumn{7}{|c|}{$\mathrm{BC}\left(\mathrm{t} \mathrm{ha}^{-1}\right)$} \\
\hline 0 & $25.48^{c}$ & $13.89^{c}$ & $7.48^{c}$ & $27.05^{\mathrm{c}}$ & $10.65^{\mathrm{c}}$ & $49.37^{\mathrm{d}}$ \\
\hline 4 & $27.03^{b}$ & $14.82^{\mathrm{b}}$ & $7.82^{b}$ & $29.01^{\mathrm{b}}$ & $11.42^{\mathrm{b}}$ & $55.31^{\mathrm{c}}$ \\
\hline 8 & $27.70^{\mathrm{ab}}$ & $15.43^{\mathrm{ab}}$ & $8.44^{\mathrm{a}}$ & $31.45^{\mathrm{a}}$ & $11.63^{\mathrm{ab}}$ & $65.11^{\mathrm{b}}$ \\
\hline 12 & $28.78^{a}$ & $15.96^{\mathrm{a}}$ & $8.45^{\mathrm{a}}$ & $31.38^{\mathrm{a}}$ & $12.12^{\mathrm{a}}$ & $69.74^{\mathrm{a}}$ \\
\hline LSD (0.05) & 1.46 & 0.75 & 0.32 & 0.91 & 0.57 & 3.35 \\
\hline \multicolumn{7}{|c|}{ N/P $\left(\mathrm{kg} \mathrm{ha}^{-1}\right)$} \\
\hline $00 / 00$ & $24.81^{\mathrm{c}}$ & $14.32^{\mathrm{b}}$ & $7.46^{\mathrm{d}}$ & $28.58^{\mathrm{b}}$ & $10.78^{b}$ & $52.25^{\mathrm{d}}$ \\
\hline $60 / 10$ & $26.14^{\mathrm{c}}$ & $14.67^{\mathrm{b}}$ & $7.82^{\mathrm{c}}$ & $29.90^{\mathrm{b}}$ & $11.09^{\mathrm{b}}$ & $56.57^{\mathrm{c}}$ \\
\hline $90 / 15$ & $28.04^{b}$ & $14.89^{b}$ & $8.21^{b}$ & $30.57^{\mathrm{a}}$ & $11.93^{\mathrm{a}}$ & $62.49^{b}$ \\
\hline $120 / 20$ & $30.01^{\mathrm{a}}$ & $16.22^{\mathrm{a}}$ & $8.70^{\mathrm{a}}$ & $30.85^{\mathrm{a}}$ & $12.02^{\mathrm{a}}$ & $68.21^{\mathrm{a}}$ \\
\hline LSD (0.05) & 1.46 & 0.75 & 0.32 & 0.91 & 0.57 & 3.35 \\
\hline $\mathrm{CV}(\%)$ & 7.53 & 7.01 & 5.64 & 4.28 & 6.95 & 7.85 \\
\hline
\end{tabular}

Means within the same factor and column followed by the same letter are not significantly different at $\mathrm{p} \geq 0.05$ levels of significance; PH= Plant height; RL=Root Length; NL= Number of Leaves; RD= Root Diameter; RCD=Root Core Diameter; RV= Root Volume NS = Non significant 


\section{Yield Parameters of Carrot}

Total root yield, marketable and unmarketable yield, percentage of forked/branched root, and percentage of cracking root carrot were significantly $(\mathrm{P}<0.05)$ influenced by the main effects of both biochar and inorganic N/P fertilizer application (Table 8).

\section{Total Root Yield}

The highest total root yield (44037.0 $\mathrm{kg} \mathrm{ha}^{-1}$ ) was obtained from the plot applied with biochar at the rate of 12 $\mathrm{t} \mathrm{ha}^{-1}$, while the lowest total root yield $\left(30208.00 \mathrm{~kg} \mathrm{ha}^{-1}\right)$ was obtained from plots without biochar (Table 5). However the total yield advantages for 4,8 and $12 \mathrm{t}$ of biochar over the control were 18.54, 34.34, and 45.80\% respectively. Further applications of biochar above $8 \mathrm{t} \mathrm{ha}^{-1}$ did not bring a significant yield change, suggesting that $8 \mathrm{t}$ $\mathrm{ha}^{-1}$ is the optimum rate. Generally, total yield of carrot resulted from increased rates of applied biochar. Likewise, simple correlation analysis between total yield of carrot roots and biochar rates showed a positive and significant relation with $\left(\mathrm{r}=0.51^{*}\right)$ (Table 6$)$.

Application of inorganic N/P fertilizer at different rates for carrot total root yield was found to have a significant $(\mathrm{P}<0.01)$ effect (Table 8$)$. The total root yield ranged from 25860.0 to $47954.0 \mathrm{~kg} \mathrm{ha}^{-1}$. The maximum total root yield was obtained from the plots grown with the application of $120 / 20 \mathrm{~kg} \mathrm{ha}^{-1} \mathrm{~N} / \mathrm{P}$ fertilizers, which was significantly differed from other treatments. The minimum total root yield was obtained from plot without application of N/P fertilizers. The increments in total root yield obtained with $60 / 10,90 / 15$ and $120 / 20 \mathrm{~kg} \mathrm{ha}^{-1} \mathrm{~N} / \mathrm{P}$ rates over the $0 \mathrm{~kg} \mathrm{ha}^{-1} \mathrm{~N} / \mathrm{P}$ application were 40.4, 56.66 and $85.44 \%$ respectively.

Generally, total carrot yield as shown in (Table 8) are also supported by the positive and significant correlation between total root yield with biochar application $\left(\mathrm{r}=0.51^{*}\right)$, plant height $\left(\mathrm{r}=0.79^{* * *}\right)$, root length $\left(\mathrm{r}=0.78^{* * *}\right)$ and root volume $\left(\mathrm{r}=0.0 .87^{* *}\right)$. The positive response of total yield of carrot to the application of biochar might be related to the capacity of biochar to provide essential plant nutrients.

\section{Marketable Yield}

The highest marketable root yield $\left(32.90 \mathrm{t} \mathrm{ha}^{-1}\right)$ was obtained from the plot received with biochar at the rate of 12 $\mathrm{t} \mathrm{ha}^{-1}$ was applied, while the lowest marketable root yield (23.63 $\mathrm{kg} \mathrm{ha}^{-1}$ ) was obtained from plots without biochar application. Even though, among treatments of 4 and $8 \mathrm{tha}$ ${ }^{1}$ and also, marketable carrot yield increased by $20.10,28.97$, 30.00 and $39.23 \%$ compared to the control treatment, respectively (Table 5). Further applications of biochar rate above $8 \mathrm{t} \mathrm{ha}^{-1}$ did not bring significant effect suggesting that $8 \mathrm{t} \mathrm{ha}^{-1}$ is the optimum rate to obtain highest marketable carrot yield. Likewise, marketable yield of carrot roots increased with increasing rates of biochar. Simple correlation analysis between marketable yield of carrot roots and biochar rates $\left(\mathrm{r}=0.53^{*}\right)$ were also positive and significant (Table 6). As general reason by different finding reports were explained, increased yield in biochar amendment soils due to effects of biochar on soil physico-chemical properties (Sohi et al., 2009). This result was in line with Singh et al. (2010) who suggested that timely availability of $\mathrm{N}$ could be insured and corn productivity can be positively increased, because biochar efficiently adsorbs ammonia and acts as a binder for ammonia in soil (Iyobe et al, 2004).
Application of inorganic N/P fertilizer was found to have significant $(\mathrm{P}<0.01)$ effect on the marketable yield (Table 6). It ranged from 18.88 to $35.56 \mathrm{t} \mathrm{ha}^{-1}$. The maximum marketable root yield $\left(35.56 \mathrm{t} \mathrm{ha}^{-1}\right)$ was obtained from $120 / 20 \mathrm{~kg} \mathrm{ha}^{-1} \mathrm{~N} / \mathrm{P}$ fertilizers, which was significantly different from other treatments (Table 8 ). The minimum marketable root yield $\left(18.88 \mathrm{tha}^{-1}\right)$ was obtained from plots without application of N/P fertilizers. The increments in marketable root yield obtained with 60/10, 90/15 and $120 / 20 \mathrm{~kg} \mathrm{ha}^{-1} \mathrm{~N} / \mathrm{P}$ rates over the $0 \mathrm{~kg} \mathrm{ha}^{-1} \mathrm{~N} / \mathrm{P}$ application were $34.39,41.78$ and $46.92 \%$, respectively. Generally, marketable root yield of carrot increased consistently with increased rates of applied N/P fertilizer. Similarly, Hossain (2005) found the highest marketable yield by applying N/P fertilizers at 140, 40 and $80 \mathrm{~kg} \mathrm{ha}^{-1}$ nitrogen, phosphorus and potassium respectively.

\section{Forked and Cracked Yield}

The highest forked amount of carrot roots $(7.22 \%)$ was found from $12 \mathrm{t} \mathrm{ha}^{-1}$ biochar treatment followed by treatment the $8 \mathrm{t} \mathrm{ha}^{-1}$ biochar $(7.08 \%)$. Both of these treatments did not show significant difference between each other. The control had resulted the lowest forked roots (5.34\%) followed by $4 \mathrm{t} \mathrm{ha}^{-1}$ biochar $(5.85 \%)$ which was not significantly different from each other (Table 8 ).

The application of N/P fertilizer increased significantly $(\mathrm{P}<0.01)$ forked percentage of carrot roots. The forked amount of carrot roots was found to be higher $(9.08 \%)$ and significantly differed at N/P application rate of $120 / 20 \mathrm{~kg}$ $\mathrm{ha}^{-1}$ (Table 8$)$. The addition of mineral fertilizers did not result in significantly different forked roots of carrot up to 90/15 kg ha-1 N/P. However, Zakir et al. (2012) reported application of inorganic fertilizer markedly increased branched or forked roots.

\section{Harvest Index}

Different rate of biochar did not significantly $(\mathrm{P}>0.05)$ affect harvest index (HI) of carrot (Table 8). However, HI of carrot varied for different rates of biochar application from 0 to $12 \mathrm{t} \mathrm{ha}^{-1}$ numerically, $\mathrm{HI}$ ranging from $76.13 \%$ to $78.61 \%$ from 0 to $12 \mathrm{t} \mathrm{ha}^{-1}$ application of biochar.

Application of N/P fertilizer influenced HI of carrot significantly $((\mathrm{P}<0.05)$. However, further application of N/P fertilizer above 60/10 $\mathrm{kg} \mathrm{ha}^{-1}$ did not result in significant increment of $\mathrm{HI}$ of carrot. Numerically, soils treated with $120 / 20 \mathrm{~kg} \mathrm{ha}^{-1} \mathrm{~N} / \mathrm{P}$ fertilizer had resulted in higher HI (81.11\%) compared to control (Table 8). According to Ahmad (2014), carrot harvest index was positively increased with increased $\mathrm{N}$ fertilizer. On the other hand, HI and total yield had shown strong positive relationship $\left(\mathrm{r}=0.79^{* *}\right)$

\section{Unmarketable Yields}

As shown in (Table 7), unmarketable carrot yield was significantly $(\mathrm{P}<0.05)$ affected by application of biochar and N/P fertilizer and the interaction between biochar rates and N/P fertilizer. The highest mean unmarketable carrot yield (17264.80) was recorded with the application of $12 \mathrm{t}$ $\mathrm{ha}^{-1}$ biochar and 120/20 $\mathrm{kg} \mathrm{ha}^{-1} \mathrm{~N} / \mathrm{P}$ fertilize which was similar to $8 \mathrm{t} \mathrm{ha}^{-1}$ biochar and $120 / 20 \mathrm{~kg} \mathrm{ha}^{-1} \mathrm{~N} / \mathrm{P}$ fertilize (15807.50) while the minimum unmarketable carrot yield (3070.00) was recorded. 
Table 8. Effects of dung cake biochar and inorganic N/P fertilizer rates on total root, marketable, forked, cracked root yield and harvest index of carrot

\begin{tabular}{|c|c|c|c|c|c|}
\hline & $\begin{array}{c}\text { TRY } \\
\left(\mathrm{t} \mathrm{ha}^{-1}\right)\end{array}$ & $\begin{array}{c}\text { MY } \\
\left(\mathrm{t} \mathrm{ha}^{-1}\right)\end{array}$ & $\begin{array}{l}\text { FR } \\
(\%)\end{array}$ & $\begin{array}{l}\mathrm{CR} \\
(\%)\end{array}$ & $\begin{array}{l}\mathrm{HI} \\
(\%)\end{array}$ \\
\hline \multicolumn{6}{|c|}{$\mathrm{BC}\left(\mathrm{t} \mathrm{ha}^{-1}\right)$} \\
\hline 0 & $30.21^{\mathrm{c}}$ & $23.63^{c}$ & $5.34^{b}$ & $0.14^{\mathrm{c}}$ & 76.13 \\
\hline 4 & $35.81^{\mathrm{b}}$ & $28.38^{\mathrm{b}}$ & $5.85^{\mathrm{b}}$ & $0.40^{\mathrm{b}}$ & 78.18 \\
\hline 8 & $40.58^{\mathrm{a}}$ & $30.72^{\mathrm{ab}}$ & $7.08^{\mathrm{a}}$ & $0.49^{b}$ & 78.28 \\
\hline 12 & $44.04^{\mathrm{a}}$ & $32.90^{\mathrm{a}}$ & $7.22^{\mathrm{a}}$ & $1.33^{\mathrm{a}}$ & 78.61 \\
\hline LSD (0.05) & 47.04 & 3.68 & 1.08 & 0.11 & Ns \\
\hline \multicolumn{6}{|c|}{ N/P $\left(\mathrm{kg} \mathrm{ha}^{-1}\right)$} \\
\hline $0 / 0$ & $25.86^{\mathrm{c}}$ & $18.88^{c}$ & $5.87^{b}$ & $0.20^{\mathrm{c}}$ & $72.46^{\mathrm{b}}$ \\
\hline $60 / 10$ & $36.31^{\mathrm{b}}$ & $28.77^{\mathrm{b}}$ & $5.64^{b}$ & $0.09^{d}$ & $79.23^{\mathrm{a}}$ \\
\hline $90 / 15$ & $40.51^{b}$ & $32.42^{\mathrm{ab}}$ & $4.91^{b}$ & $0.94^{b}$ & $78.41^{\mathrm{a}}$ \\
\hline $120 / 20$ & $47.95^{\mathrm{a}}$ & $35.56^{\mathrm{a}}$ & $9.08^{\mathrm{a}}$ & $1.12^{\mathrm{a}}$ & $81.11^{\mathrm{a}}$ \\
\hline LSD (0.05) & 4.70 & 3.68 & 1.08 & 0.11 & 3.06 \\
\hline $\mathrm{CV}(\%)$ & 17.30 & 17.64 & 23.47 & 25.35 & 5.43 \\
\hline
\end{tabular}

TRY=Total root yield, MY=marketable yield, FR=Forked root, and CR=Cracked root; HI=Harvest index; Means within the same factor and column followed by the same letter are not significantly different at $\mathrm{P} \geq 0.05$ level of significance; NS $=$ Non-significant.

Table 9. Simple correlation coefficients (r) values between growth parameters, total root yield and yield components of carrot

\begin{tabular}{l|llllllllll} 
& BC & PH & RL & RD & RV & TRY & MY & UMY & FRY & CRY \\
\hline BC & 1.00 & $0.83^{* *}$ & $0.58^{*}$ & $0.44^{\text {ns }}$ & $0.59^{*}$ & $0.51^{*}$ & $0.53^{*}$ & $0.52^{*}$ & $0.43^{\text {ns }}$ & $0.48^{\text {ns }}$ \\
PH & & 1.00 & $0.82^{* *}$ & $0.79^{* *}$ & $0.89^{* *}$ & $0.79^{* *}$ & $0.78^{* *}$ & $0.68^{*}$ & $0.62^{*}$ & $0.63^{*}$ \\
RL & & & 1.00 & $0.76^{* *}$ & $0.89^{* *}$ & $0.78^{* *}$ & $0.73^{* *}$ & $0.76^{* *}$ & $0.72^{* *}$ & $0.53^{*}$ \\
RD & & & & 1.00 & $0.94^{* *}$ & $0.85^{* *}$ & $0.89^{* *}$ & $0.65^{*}$ & $0.62^{*}$ & $0.64^{*}$ \\
RV & & & & & 1.00 & $0.87^{* *}$ & $0.88^{* *}$ & $0.78^{* *}$ & $0.76^{* *}$ & $0.68^{* *}$ \\
TRY & & & & & & 1.00 & $0.97^{* *}$ & $0.89^{* *}$ & $0.86^{* *}$ & $0.67^{* *}$ \\
MY & & & & & & & 1.00 & $0.72^{* *}$ & $0.69^{* *}$ & $0.56^{*}$ \\
UMY & & & & & & & & 1.00 & $0.96^{* *}$ & $0.67^{* *}$ \\
FRY & & & & & & & & & 1.00 & $0.49^{\text {ns }}$ \\
\hline NS $* * *=$ Non
\end{tabular}

NS,*,**=Non-significant, Significant at 0.05 and 0.01 Probability Level; BC=biochar, PH=Plant Height; RL= Root Length, RD= Root Diameter, RV=Root Volume, TRY=Total Root Yield, MY=Marketable Yield, UMY= Unmarketable Yield, FRY=Forked Root Yield, CRY=Cracked Root Yield.

Table 7. Unmarketable root yield $\left(\mathrm{kg} \mathrm{ha}^{-1}\right)$ of carrot as influenced by interaction of biochar and inorganic N/P fertilizer rates

\begin{tabular}{l|cccc}
\hline \multirow{2}{*}{$\mathrm{N} / \mathrm{P}\left(\mathrm{kg} \mathrm{ha}^{-1}\right)$} & \multicolumn{4}{|c}{ Biochar rates $\left(\mathrm{t} \mathrm{ha}^{-1}\right)$} \\
\cline { 2 - 4 } & 0 & 4 & 8 & 12 \\
\hline $0 / 0$ & $3070.00^{\mathrm{f}}$ & $4971.00^{\mathrm{e}}$ & $5670.50^{\mathrm{de}}$ & $6961.90^{\mathrm{cd}}$ \\
$60 / 10$ & $5875.90^{\mathrm{de}}$ & $4812.60^{\mathrm{ef}}$ & $6902.80^{\mathrm{cd}}$ & $7918.80^{\mathrm{bc}}$ \\
$90 / 15$ & $5904.90^{\mathrm{de}}$ & $6053.80^{\mathrm{de}}$ & $6943.20^{\mathrm{cd}}$ & $8870.30^{\mathrm{b}}$ \\
$120 / 20$ & $6372.50^{\mathrm{de}}$ & $9060.00^{\mathrm{b}}$ & $15807.50^{\mathrm{a}}$ & $17264.80^{\mathrm{a}}$ \\
\hline LSD (5\%) & & 1861.2 & \\
CV (\%) & & 14.91 & \\
\hline
\end{tabular}

Means within the same column and row followed by the same letter are not significantly different at $\mathrm{p} \geq 0.05$ level of significance; NS $=$ Non significant

\section{Conclusions}

There are a lot of research done relation to biochar as agricultural soil amendment to improve soil physicochemical properties and enhance soil productivity to its effect with and without combination of inorganic fertilizer for the improvement of crop productivity and sustainable soil fertility management. This research was conducted to address whether the dung cake biochar will improve crop productivity and enhance soil fertility under small holder farmers of Debre Birhan Zuria District. Hence, applications of biochar as fertilizer source have a paramount importance to improve carrot production while improving the soil physical and chemical properties on Vertisols. In addition, carrot yield response and $\mathrm{N}$ and $\mathrm{P}$ uptake with application of biochar even in the absence of inorganic NP fertilizer seems respond comparable with that of inorganic nitrogen-phosphorus fertilizers. Thus, in addition to using dung cake as fuel source, application of biochar as nutrient source could be another alternative to achieve sustainable carrot production on Vertisols of North Shoa of Debre Birhan District as well as elsewhere with similar agro-ecologies. However, further field studies on biochar application methods and rates and soil amendment needs in depth study based on its socio-economic and technical applicability by considering local resource application methods.

\section{References}

Abayneh E, Gebeyhu B, Kebede A. 2006. Soils of Debre Birhan Agricultural Research Center. Technical Paper No 77. EARO, Addis Ababa, Ethiopia.

Abdelmawly SE. 2004. Growth, yield, N uptake and water use efficiency of carrot (Daucus carota 1.) Plants as influenced by irrigation level and nitrogen fertilization rate. UniversityBulletin Environmental Research, 7:1. 
Abebe N, Endalkachew K, Mastawesha M, Gebermedihin A. 2012. Effect of Biochar Application on Soil Properties and Nutrient Uptake of Lettuces (Lactuca sativa) Grown in Chromium Polluted Soils. American-Eurasian Journal of Agricultural and Environmental Science, 12 (3): 369-376.

Anderson, P. 2009. 'Construction plans for the Champion-2008 TLUD gasifer cook stove', edition 1.1.

Arocena JM, Opio C. 2003. Prescribed fire-induced changes in properties of sub-boreal forest soils. Geoderma, 113: 1-16.

Ayabana A, Jenkinson DS. 1990. Decomposition of C-14 labelled reygrass and maize under tropical conditions. Soil Science Society of American Journal, 54: 112-115

Bayu D, Gezahegn B, Solomon T. 2015. Characterization of Biochar Produced at Different Temperatures and its Effect on Acidic Nitosol of Jimma, Southwest Ethiopia. International Journal of Soil Science, 10: 63-73

Bender I, Ess M, Matt D, Moor U, Tonneutare T, Luik A. 2009. Quality of organic and conventional carrots. Agronomy Research, 7(2): 572-57.

Chan KY, Xu K. 2009. Biochar Nutrient properties and their enhancement. Science and Technology. Earth scan, London.

Chan KY, Zwieten L, Meszaros I, Downie A, Joseph S. 2007. Agronomic values of green waste biochar as a soil amendment. Australian Journal of Soil Research, 45: 629634.

DeLuca TH, McKenzie MD, Gundale MJ, Holben WE. 2006. Wildfire produced charcoal directly influences nitrogen cycling in ponderosa pine forests. Soil Science Society of American Journal, 70: 448-453.

Ellen RG, Yael MH, Max K, Eddie C, Avner S, Dalia RD, Ludmilla T, Menahem B, Yigal E. 2010. Biochar impact on development and productivity of pepper and tomato grown in fertigated soilless media Plant Soil. http://10.1007/s11104010-0544-6

FAO.1990. Food and Agriculture Organization of the United Nations. Guidelines for profile description. $3^{\text {rd }}$ Edition. Rome.

Getachew T, Mohammed Y. 2013. Production Manuals of Carrots. Carrot Aid Ethiopia. Denmark. www.carrotaid.org

Glaser B, Lehmann J, Zech W. 2002. Ameliorating physical and chemical properties of highly weathered soils in the tropics with charcoal a review. Biology and Fertility of Soils, 35: 219-230. DOI:10.1007/S00374-002-0466-4

Iyobe T, Asada T, Kawata K, Oikawa K. 2004. Comparison of removal efficiencies for ammonia and amine gases between woody charcoal and activated carbon. Journal of Health Science, 50: 148-153.

Jien SH, Wang CS. 2013. Effects of biochar on soil properties and erosion potential in a highly weathered soil. Catena, 110: 225233.

Jones BEH, Haynes RJ, Phillips IR. 2010. Effect of amendment of bauxite processing sand with organic materials on its chemical, physical and microbial properties. Journal of Environmental Management, 91: 2281-2288.

Laird DA, Fleming P, Davis DD, Hortonne R, Wang BQ, Karlen DL. 2010. Impact of biochar amendments on the quality of a typical mid western agricultural soil. Geoderma, 158: 443-449.

Landon JR. 1991. Booker tropical soil manual: A handbook for soil survey and agricultural land evaluation in the tropics and sub-tropics. Longman Scientific and Technical, Essex, New York. p. 474.

Lehmann J, Gaunt J, Rondon M. 2006. Biochar sequestration in terrestrial ecosystems. Mitigation. Adaptation. Strategic Global Change, 11: 395-419.

Lehmann J, Pereira da SJ, Steiner C, Nehls T, Zech W, Glaser B. 2003. Nutrient availability and leaching in an archaeological Anthrosol and a Ferralsol of the Central Amazon basin: fertilizer, manure and charcoal amendments. Plant and Soil, 249: 343-357.

Lehmann J. 2007. Carbon sequestration in dry land ecosystems. Journal of Environmental Management, 33: 528-544.
Liang B, Lehmann J, Solomon D, Kinyangi J, Grossman J, O'Neill B. 2006. Black carbon increases cation exchange capacity in soils. Soil Sci. Soc. Am. J. 70, 1719-1730.

Marian O, Ekebafe P, Oviasogi N, Osasuyi A. 2014. Effect of Indigenous Palm Fronds and Cow dung Biochar and its Blends on Soil Properties. Growth Assessment of Oil Palm Seedlets International Conference on Sustainable Environment and Agriculture IPCBEE vol. 76 IACSIT Press, Singapore. DOI: 10.7763/IPCBEE. 2014. V76. 18

Martinsen V, Mulder J, Shitumbanuma V, Sparrevik M, Borresen T, Cornelissen G. 2014. Farmer-led maize biochar trials: Effect on crop yield and soil nutrients under conservation farming. Journal of Plant Nutrition and Soil Science. 177:681-695.

Melisew S. 2002. Over view of the Electricity Sector in Relation to Public- Private Partnerships in Ethiopia.

Moniruzzaman M, Akand M, Hossain H, Sarkar MI, Ullah A. 2013. Effect of Nitrogen on the Growth and Yield of Carrot (Daucus carota L.) The Agriculturists, 11: 76-81.

Mubashir M, Malik S, Akhan AA, Ansari TM, Wright S, Brown MV, Islam KR. 2010. Growth, Yield and Nitrate Accumulation of Irrigated Carrot and Okra in Response to Nitrogen Fertilization Pakistan Journal of Botany. 42:25132521.

Muter O, Lebedeva G, Telysheva G. 2014. Evaluation of the changes induced by gasification biochar in a peat-sand substrate. International journal of Agrophysics, 28:471-478. DOI: 10.2478/intag-2014-0037

Niemeyer T, Niemeyer M, Mohamed A, Fottner S, Hardtle W. 2005. Impact of prescribed burning on the nutrient balance of heath lands with particular reference to nitrogen and phosphorus. Journal of Applied Vegetable Science, 8:183192.

Openshaw K.1998. Estimating biomass supply: Focus on Africa. Pereira RG, Heinemann AB, Madari BE, Carvalho MTM, Kliemann HJ and Santos AP. 2012 Transpiration response of upland rice to water deficit changed by different levels of eucalyptus biochar. Pesq Agropec Bras, 47: 716-21.

Raynal LC. 1994. Nitrogen nutrition of carrots. Proceedings of the third congress of the European Society for Agronomy, Padova, Italy. pp 616-617 reassessment. AFTES Working paper No. 17. World Bank, Washington DC, 48p.

Rondon MA, Lehmann J, Ramirez J, Hurtado M. 2007. Biological nitrogen fixation by common beans (Phaseolus vulgaris L.) increases with bio-char additions. Biology and Fertility of Soils, 43: 699-708. DOI:10.1007/s00374-0060152-z

Sanderson KR, Ivany JA. 1997. Carrot yield response to nitrogen rate. Journal of Production Agriculture, 10:336-339.

Sarah H, Gibson S, Jeremy S, Kalves W, Mathews C, Sinabu M, Joseph K, Matanda Victor S, Edward B, Samuel A, Hans P, Schmidt Jan M, Magdalena R. 2014. Improving crop yield and storing carbon. No 20100920-10 Phase 2. report 4.

SAS 2002. Statistical Analysis System, Usage and reference. Version 6. 501 p. SAS Institute, Cary, North Carolina, USA. Shafique Mazhar. 2016. Effect of different NP levels on root yield and its contributing characters of carrot Dacus carota L. Life Science International Journa, 10:16-20.

Shinogi Y. 2004. Nutrient leaching from carbon products of sludge. In ASAE/CSAE Annual International Meeting. Paper No. 044063. Ottawa, Ontario, Canada.

Singh B, Singh BP, Cowie AL. 2010. Characterization and evaluation of biochars for their application as a soil amendment. Australian Journal of Soil Research, 48:516-52 Sisay Hailu, Tilahun Seyoum and Nigussie Dechassa. 2008. African Journal of Biotechnology, 7: 27-34

Solaiman Z, Blackwell P, Abbott L, Storer P. 2010. Direct and residual effect of biochar application on mycorrhizal root colonization, growth and nutrition of wheat. Australian Journal of Soil Research, 48: 546-55. 
Utomo WH, Sukartonneo WH, Nugroho, Z. and Kusuma, 2011. Simple Biochar Production Generated From Cattle Dung and Coconut Shell. Journal Basic of Applied. Science Research 10:1680-1685.

Venkatesh G, Venkateswarlu B, Gopinat KA, Srinivasarao C, Korwar GR, Reddy SB. 2013. Low cost portable kiln for Biochar production, NICRA Technical Boucher.

Vivek IS, Chakor. 1992. Effects of nitrogen and irrigation on growth and yield of sunflower (Helianthus annuus) under mid-hill conditions of Himachal Pradesh. Indian Journal of Agronomy. 37: 500-502.

Yuan JH, Xu RK. 2011. The amelioration effects of low temperature biochar generated from nine crop residues on an acidic Ultisol. Soil Use and Management 27:110-115.
Zakir HM, Sultana MN, Saha K. C.2012. Influence of Commercially Available Organic vs Inorganic Fertilizers on Growth Yield and Quality of Carrot. Journal of Environmental Science and Natural Resources, 5: 39-45.

Zhang AF, Bian RJ, Pan GX, Cui LQ, Hussain Q, Li LQ, Zheng JW, Zheng JF, Zhang XH, Han XJ. 2012. Effects of biochar amendment on soil quality, crop yield and greenhouse gas emission in a chinese rice paddy: A field study of 2 consecutive rice growing cycles. Field Crops Research, 127: 153-160.

Zimmerman A. 2010. Abiotic and microbial oxidation of laboratory-produced black carbon (biochar). Journal of Environ Science Technology, 44: 1295-13. 